\title{
Urinary Leucocyte Excretion in Hypertension in Pregnancy
}

\author{
M. A. CHADD, $§ \S$ M.B., B.CH., D.C.H. ; D. MICHAEL HUMPHREYS,* M.B., CH.B \\ H. M. LEATHER, $\dagger$ M.D., M.R.C.P. ; S. A. WILLS, $\ddagger$ A.I.M.L.T.
}

Brit. med.F., 1967, 4, 655-656

Little (1966) showed that urinary white cell excretion rates were normal-that is, less than 200,000 per hour-in $95 \%$ of pregnant women free from bacteriuria and in only $28 \%$ with bacteriuria. Kincaid-Smith and Bullen (1965) found persistently raised urinary white cell excretion rates, despite successful treatment of bacteriuria, in pregnant women who were subsequently found to have established renal disease. Cross and Leather (1965) reported abnormal white cell excretion rates in hypertension in pregnancy irrespective of the clinical cause of the hypertension. The present study has been made to determine how long after delivery this abnormal leucocyte excretion persists, what relation it bears to continued hypertension in the post-partum period, and in particular whether it is associated with pyelonephritis.

The series includes 61 patients with hypertension in pregnancy and a further control group of 54 normotensive pregnant subjects. The effect on the leucocyte excretion of a course of ampicillin in 26 of the hypertensive patients and of lowering the blood pressure with hypotensive drugs in a further 15 patients was determined.

\section{Material and Methods}

Control subjects were healthy normotensive pregnant women from 16 to 38 weeks of gestation, with no history of urinary tract infection and in whom the urine was sterile. The hypertensive patients' period of gestation ranged from 16 to 36 weeks. For the purpose of this study hypertension was defined as a diastolic blood pressure of $90 \mathrm{~mm}$. Hg or more, and at least two such readings were required before admission to the series. Urinary leucocyte excretion before and after prednisolone provocation was determined by the method of Houghton and Pears (1957) with the modification that three urine specimens were collected at 90-minute intervals after prednisolone. To avoid contamination of the urine, specimens were collected by the method of Leather and Hutchings (1960). Resting leucocyte excretion levels below 200,000 cells/hour were regarded as normal (Little, 1966). A prednisolone provocation test was regarded as positive when in one of the postprednisolone urine specimens the leucocyte excretion rate was double that of the control period and also exceeded 300,000 cells/hour (Leather, Wills, and Gault, 1963). Urine was cultured on blood agar and MacConkey's media. In all cases a colony count was performed with the serial dilution technique. Urine studies were repeated throughout pregnancy and at intervals up to one year after delivery. Excretion urography was carried out in the hypertensive patients two months or more after delivery.

\section{Results}

Control Subjects.-The 54 normotensive patients were aged 16-43 years, and 26 were primiparae. In 16 resting leucocyte excretion was abnormal, and a further 15 became abnormal

-Research Registrar.

Consultant Physician

Technician.

Department of Clinical Research, Plymouth General Hospital

5 Present address : Department of Child Health, United Cardiff Hospitals. after prednisolone. The urine was infected ( $>100,000$ org./ ml.) in six, of whom five showed abnormal leucocyte excretion before or after prednisolone. Excretion rates were more often abnormal in late than in early pregnancy: thus 15 out of 22 pregnancies of more than 30 weeks' gestation were abnormal, compared with 16 out of 32 pregnancies of less than 30 weeks. Neither age nor parity seemed to influence the abnormal rates.

Hypertensive Subjects.-The 61 hypertensive patients were aged 19-43 years; 21 were primiparae. In 28 the resting leucocyte excretion was abnormal and in a further 20 it became abnormal after prednisolone. Thus only 13 out of the 61 were entirely normal. In all cases leucocyte excretion was estimated at least twice during the pregnancy. In nearly all cases these repeated results were in the same range as the initial count. The urine was infected in eight, of whom four showed abnormal leucocyte excretion. In contrast to the control subjects, leucocyte excretion was not raised more often late in pregnancy; thus all 13 before 30 weeks were abnormal, compared with 35 out of 48 after 30 weeks.

Effect of Blood Pressure Control on Leucocyte Excretion.Of the hypertensive patients 35 were currently in a study to determine the effect of control of hypertension in pregnancy ; 20 of these received no hypotensive agents and in 15 the blood pressure levels were controlled with hypotensive drugs. Leucocyte excretion was studied before and after a period of observation (average 67 days). Of the 20 controls, 17 were abnormal at the first count and 18 subsequently; of the 15 treated cases, 13 were abnormal at first and 11 subsequently. There was therefore no evidence that control of hypertension influenced the leucocyte excretion rate (Table I).

TABLB I.-Urinary Leucocyte Excretion During and After Pregnancy in Hypertensive Patients

\begin{tabular}{|c|c|c|c|c|c|}
\hline \multirow{3}{*}{ Group } & & \multicolumn{4}{|c|}{ Abnormal White Cell Excretion } \\
\hline & & \multicolumn{2}{|c|}{ During Pregnancy } & \multicolumn{2}{|c|}{ Post-partum } \\
\hline & & $\begin{array}{c}\text { No. } \\
\text { Studied }\end{array}$ & $\mid \begin{array}{c}\text { No. } \\
\text { Abnormal }\end{array}$ & $\begin{array}{l}\text { No. } \\
\text { Studied }\end{array}$ & $\begin{array}{c}\text { No. } \\
\text { Abnormal }\end{array}$ \\
\hline $\begin{array}{l}\text { Untreated hypertensives } \\
\text { Treated hypertensives } \ldots \\
\text { Ampicillin-treated }\end{array}$ & $\begin{array}{l}. . \\
\because\end{array}$ & $\begin{array}{l}20 \\
15 \\
26\end{array}$ & $\begin{array}{l}18 \\
11 \\
19\end{array}$ & $\begin{array}{l}15 \\
14 \\
19\end{array}$ & $\begin{array}{r}94 \\
10 \\
10\end{array}$ \\
\hline
\end{tabular}

Effect of Antibiotics on Leucocyte Excretion.-Twenty-six were given a course of ampicillin (average duration 17 days), 19 of these having abnormal counts initially. After ampicillin therapy all 19 patients remained abnormal. There was no evidence that antibiotic therapy affected the abnormal excretion rate (Table I).

Urinary Leucocyte Excretion After Delivery.-In 48 out of 61 hypertensive patients urinary leucocyte excretion was abnormal during pregnancy. Of the 48 who were restudied up to 12 months post-partum, 24 were abnormal and 24 were in the normal range; the remaining 13 failed to attend (Table I).

Urographic Findings.-Excretion urography was performed on 44 of the hypertensive patients: 27 were normal or showed non-pathological variations ; 5 showed post-pregnancy changes with dilatation of the renal pelvis and dilatation and tortuosity of the ureters, and 12 were definitely abnormal and included 
pyelonephritis ( 5 cases), renal ischaemia ( 2 cases), unilateral renal atrophy ( 2 cases), reflux hydroureter ( 2 cases), and polycystic disease (1 case).

Relation Between Urographic Findings and Abnormal Leucocyte Excretion.-White cell excretion before and after delivery was known in all patients who were radiographed. Abnormal excretion persisted after delivery in roughly the same proportion in those with normal $x$-ray pioture, post-pregnancy change, or pathological change (Table II).

TABLB II.-Relation Between Radiological Findings and Abnormal
Leucocyte Excretion

Relation Between Urographic Findings, Persistent Hypertension, and Post-partum Urinary Leucocyte Excretion.-In all 44 patients in whom excretion urography was performed leucocyte excretion was measured after delivery. In 23 it returned to normal and in 21 it remained abnormal. The incidence of normal or abnormal urographic findings and of persistent hypertension was similar in both groups (Table III).

\begin{tabular}{|c|c|c|c|c|}
\hline \multirow{2}{*}{$\begin{array}{l}\text { Urinary Leucocyte } \\
\text { Excretion }\end{array}$} & \multirow{2}{*}{ No. } & \multicolumn{2}{|c|}{ Urography } & \multirow{2}{*}{$\begin{array}{c}\text { Hyper- } \\
\text { tensive } \\
\text { Post-partum }\end{array}$} \\
\hline & & Negative & Positive & \\
\hline $\begin{array}{l}\text { Returned to normal } \ldots \\
\text { Remained abnormal .. }\end{array}$ & $\begin{array}{l}23 \\
21\end{array}$ & $\begin{array}{l}15 \\
12\end{array}$ & $\begin{array}{l}8 \\
9\end{array}$ & $\begin{array}{l}11 \\
10\end{array}$ \\
\hline
\end{tabular}

\section{Discussion}

Both normotensive and hypertensive non-infected nonpregnant women give urinary leucocyte excretion rates within the accepted range of normal (Pears and Houghton, 1959 ; Hutt et al., 1961), and Little (1966) reported normal excretion rates in a very high proportion of pregnant women without bacteriuria. Cross and Leather (1965) reported raised urinary leucocyte excretion before or after prednisolone provocation in 29 out of 31 pregnancies complicated by hypertension but without bacteriuria.

In the present series of 115 pregnant women, urinary white cell excretion was abnormal in more than $50 \%$ of apparently normal subjects and in $80 \%$ of hypertensive patients. There was no evidence from association with symptoms of urinary tract infection, positive urine cultures, or response to antibiotics that it was necessarily a manifestation of infection in the urinary tract. In the hypertensive group it was not modified by the use of hypotensive drugs and had no clear association with the persistence or otherwise of hypertension after pregnancy. Finally, there was no evidence from the subsequent urographic findings that it bore any relation to established renal disease as assessed by radiology.

The reason for the increased urinary leucocyte excretion in pregnancy remains therefore unexplained. It is possible that it represents some form of vascular response to the pregnancy itself, since there was evidence in some of the groups studied that the number of abnormal tests increased with advancing gestation and that in some of the cases it returned to normal after pregnancy. However, its value as evidence of infection or of anatomical abnormality of the urinary tract appears to be negligible.

\section{Summary}

Urinary leucocyte excretion was abnormal before or after prednisolone provocation in 31 out of 54 normotensive pregnant subjects and 48 out of 61 hypertensive pregnant subjects. In the hypertensive group treatment with antibiotics or hypotensive agents failed to alter the abnormal leucocyte excretion, which in nearly half the cases returned spontaneously to normal after delivery. There was no evidence that abnormal leucocyte excretion was a manifestation of pyelonephritis or that it bore any relation to the persistence or otherwise of hypertension after delivery.

We wish to thank the obstetricians of the Plymouth General Hospital-Messrs. J. G. Dumoulin, G. M. Davidson, and I. Cunningham-for ready access to patients under their care and for encouragement and help during this study. We are grateful to Dr. H. T. ApSimon for reviewing the radiographs. Three of us (M. A. C., D. M. H., and S. A.W.) were in receipt of research grants from the Research Committee of the South-western Regional Hospital Board.

\section{REFERRNCBS}

Cross, H. C., and Leather, H. M. (1965). Lancet, 1, 1197.

Houghton, B. J., and Pears, M. A. (1957). Brit. med. f., 1, 622.

Hutt, M. S. R., Chalmers, J. A., MacDonald, J. S., and de Wardener. H. E. (1961). Lancet, 1, 351 .

Kincaid-Smith, P., and Bullen, M. (1965). Ibid., 1, 395.

Leather, H. M., and Hutchings, M. T. (1960). Ibid., 2, 654.

—Wills, M. R., and Gault, H. M. (1963). Brit. med. F., 1, 92.

Little, P. J. (1966). Lancet, 2, 925.

Pears, M. A., and Houghton, B. J. (1959). Ibid., 2, 1167. 